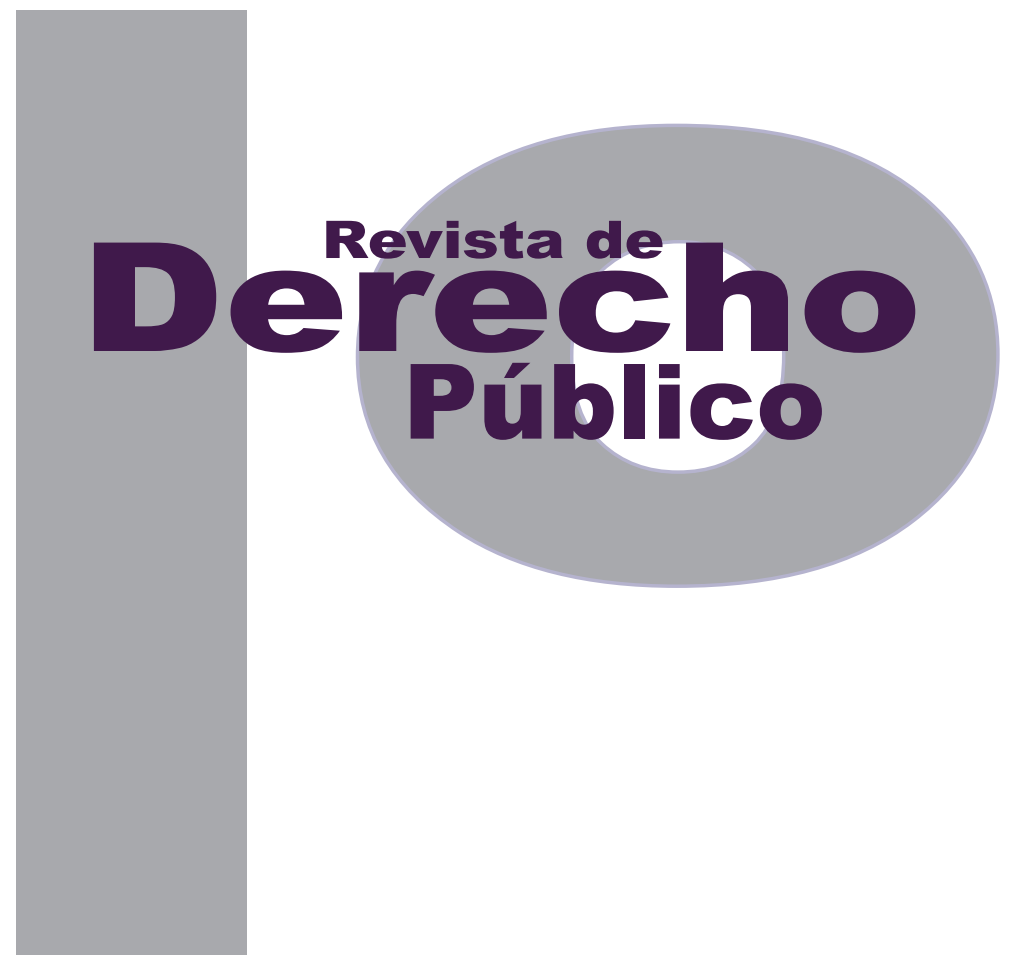

\title{
EL ASILO POLÍTICO: CLAVES NARRATIVAS
}

\author{
MAURICIO Moscoso DíAZ
}

Artículo de revisión

DOI: http://dx.doi.org/10.15425/redepub.34.2015.32

Universidad de los Andes

Facultad de Derecho

Revista de Derecho Público N. ${ }^{\circ} 34$

Enero - Junio de 2015. ISSN 1909-7778 


\section{El asilo político: claves narrativas}

\section{Resumen}

El presente texto aborda el asilo político como un tema central del derecho internacional. El objetivo consiste en analizar la dimensión discursiva que encierra esta institución jurídica a partir de dos elementos centrales: a) el exhorto por conseguir aprobación del lector, y b) la voluntad de rectificar el orden de los acontecimientos. Para tal fin se menciona en qué consisten las principales corrientes que integran el discurso del asilo político, enfatizando las técnicas y estrategias más relevantes en la literatura. Finalmente, se sugieren algunas limitaciones en aras de proponer debates en función del orden mundial vigente.

Palabras clave: asilo político, derecho de asilo, narrativa jurídica, Víctor Raúl Haya de la Torre, historia del derecho internacional.

\section{Politic Asylum: Key Features Narrative}

\section{Abstract}

This paper addresses the asylum as a central affair of international law. The objective is to analyze the discursive dimension that contains this legal institution from two central elements: at) the exhortation to get approval of the reader, and b) the will of rectify the order of events. For this end, it points the main currents out that integrate the discourse of Political Asylum, emphasizing the techniques and strategies most used by legal literature. Finally, some limitations are suggested in order to display the new challenges in the current world order.

Keywords: politic asylum, right of asylum, legal narrative, Víctor Raúl Haya de la Torre, History of International Law.

\section{0 asilo político: chaves narrativas}

\section{Resumo}

O presente texto aborda o asilo político como um tema central do direito internacional. 0 objetivo consiste em analisar a dimensão discursiva que encerra esta instituição jurídica a partir de dois elementos centrais: a) o exorto por conseguir aprovação do leitor, e b) a vontade de retificar a ordem dos acontecimentos. Para tal fim se menciona em que consistem as principais correntes que integram o discurso do asilo político, enfatizando as técnicas e estratégias mais relevantes na literatura. Finalmente, são sugeridas algumas limitações em aras de propor debates em função da ordem mundial vigente.

Palavras-chave: asilo político, direito de asilo, narrativa jurídica, Víctor Raúl Haya de la Torre, história do direito internacional. 


\title{
El asilo político: claves narrativas*
}

\author{
Mauricio Moscoso Díaz ${ }^{* *}$
}

\section{SUMARIO}

Introducción: el carácter diplomático del asilo político - I. EL EXHORTO PARA CONSEGUIR APROBACIÓN - A. Influencia de la historiografía hispanoamericana del siglo XIX - B. La visión naturalista - 1. Humanismo y temporalidad - II. LA VOLUNTAD DE RECTIFICAR LOS ACONTECIMIENTOS - A. La escritura oficial del asilo político - B. La lectura secular - C. La lectura sobre la memoria amenazada: poder e identidad - III. CONCLUSIONES - A. La insatisfacción por la historia tradicional - Referencias.

* Cómo citar este artículo: Moscoso Díaz, M. (Junio, 2015). El asilo político: claves narrativas. Revista de Derecho Público, 34. Universidad de los Andes (Colombia).

El presente texto es una versión abreviada de la primera parte de la tesis de maestría "El asilo político: una relectura del caso Víctor Raúl Haya de la Torre (1949-1951)", escrita durante el año 2013 bajo la dirección de la profesora SJD, Liliana Obregón T. Agradezco las pertinentes y enriquecedoras sugerencias que ella y el jurado calificador me brindaron; este último integrado por las profesoras Ana María Otero Cleves y Diana Durán Smela. De otra parte, mi evaluador anónimo me ayudó a precisar decisivos elementos conceptuales. Extiendo mi reconocimiento igualmente a la Facultad de Derecho de la Universidad de los Andes.

** Magíster en Derecho de la Universidad de los Andes, historiador de la Universidad Nacional de Colombia y abogado de la Universidad Libre. Correo: m.moscoso122@uniandes.edu.co 


\section{Introducción: la acepción diplomática del} asilo político

El presente texto aborda el asilo político como un tema central del derecho internacional. El objetivo consiste en analizar la dimensión discursiva de esta institución a partir de dos ejes. Primero, el exhorto por conseguir la aprobación del lector, y segundo, la voluntad de rectificar el orden de los acontecimientos. A partir de ellos, la dogmática y la narrativa cobraron unidad de sentido y alcanzaron una coherencia interna sustancial.

Se precisa que el estudio de los giros narrativos se concentrará en su alcance diplomático. Esto es, la protección e inviolabilidad que gozan los consulados, legaciones y embajadas extranjeras en misiones oficiales, con fundamento en el recurso de la extraterritorialidad, y de la cual deriva su beneficio una persona que ha ingresado en ellos (Ronning, 1965).

El sentido diplomático del asilo político alcanzó notoriedad con el aumento de la producción literaria que despertó el caso Víctor Raúl Haya de la Torre (Colombian Peruvian Asylum Case). Justamente, las discrepancias entre Colombia y Perú fueron un tema protagónico en los estudios latinoamericanos de derecho internacional durante la primera mitad del siglo xx, antecedidas por una célebre controversia originada en la incursión loretana a la población de Leticia, en la región del Amazonas, que derivó en la exigencia colombiana de dar cumplimiento al Tratado Salomón Lozano (1932-1933). ${ }^{1}$

1 En la primera mitad del siglo $X X$, el impacto de las discrepancias colombo-peruanas en los estudios de derecho internacional fortaleció
El litigio en torno al asilo de Haya de la Torre fue la ocasión para enrostrar las actitudes hostiles anteriores del gobierno peruano, y el escenario para orientar la discusión sobre su procedencia jurídica con base en reglas previas, incluyendo el derecho a que la persona protegida se desplazara fuera del local sin que las autoridades del Estado territorial la detuvieran, en virtud del permiso oficial denominado salvoconducto.

Sin embargo, al centrarse el debate en las vicisitudes del asilo político con base en la salvaguardia y la inmunidad de las misiones diplomáticas en el extranjero, el interés de la literatura se orientó a diferenciarlo respecto de aquellos eventos en que la extraterritorialidad y la protección transitoria en una legación no constituían los presupuestos esenciales que facilitaban la protección a un refugiado (Ronning, 1965b, págs. 5-8).

La primera diferencia fue que el asilo territorial empezó a ubicarse, entonces, como una práctica anterior que debió alterarse en el Nuevo Mundo, en razón a los requerimientos de los caudillos independentistas, en medio de las turbulencias políticas de las nacientes repúblicas

\footnotetext{
la idea de consolidar el Estado-Nación. Sobre este aspecto son útiles los análisis semióticos y lingüísticos de las narrativas que asumieron las élites sobre el territorio, las fronteras y la población bajo el ropaje de la Nación-Patria como el escenario principal de enunciación oficial, lo cual coincidió con los debates sobre la aplicación de tratados que sugerían una cartografía definida, y posteriormente las cuestiones sobre el asilo político ante la Corte Internacional de Justicia. Al respecto: Serje de la Ossa (2011); Díaz, Muñoz y Nieto (2010); Yepes (1933); Legación de Colombia en España (1933); Harley (2005) y Niño (s.f.). Será muy enriquecedora también la publicación de Carlos Humberto Camacho Arango (2013), Le Conflit de Leticia (1932-1933) et les armées du Pérou et de la Colombie: histoire - récit, histoire comparée, histoire croisée (tesis inédita de doctorado). Université Panthéon Sorbone, París, France.
} 
americanas en el siglo $x \mid x^{2}{ }^{2}$ Aunque la inviolabilidad de los locales en territorio extranjero alentó la crítica sobre la derogatoria de la soberanía nacional, esta también ayudó a precisar el principal rasgo del asilo político en su acepción diplomática.

En particular, el caso del líder peruano promovió una distancia entre el asilo político y la figura del refugio político, pese a que en el uso convencional coincidían la finalidad humanitaria y la confusión terminológica entre "asilo" y "refugio". De todas maneras el concepto de refugiado político se orientó a mitigar, en el mayor lapso, los efectos derivados de los desplazamientos masivos hacia otros Estados. ${ }^{3}$

2 La explicación tradicional que ha brindado Germán Cavelier (1960) sobre este asunto es la siguiente: "Las luchas políticas, que en América fueron la secuela de la independencia de España, tomaron pronto carácter crónico y los vencidos en ellas se venían obligados a buscar asilo en el territorio de algún Estado, con el objeto de escapar a la venganza de sus contendores (...) sin embargo, las inmensas distancias existentes entre países americanos, hacían difícil el asilo territorial, a menos que las distancias estuvieran cercanas al lugar de los trastornos políticos" (págs. 9-10).

3

Cesar Walter San Juan resalta la separación de los dos términos en su sentido primigenio. Sin embargo, el empleo indistinto de ambas nociones pudo obedecer a las siguientes causas: "a) la consideración de la tradición del asilo latinoamericano como un fenómeno autónomo; b) el uso terminológico indistinto que se hace de "asilo" y "refugio" en la normativa latinoamericana sobre asilo territorial y asilo diplomático; c) el desprestigio creciente de la práctica del asilo latinoamericano por concesiones que favorecen la impunidad, y la consiguiente necesidad de diferenciarla del sistema universal (...); g) [las] iniciativas (...) llevadas a cabo por funcionarios del ACNUR en América del Sur, que denominaron "refugio" al sistema universal de protección a los refugiados" (San Juan, 2003, pág. 37). El impacto de esta confusión consiste en reducir el alcance del Estatuto Internacional de los Refugiados que se adoptó en Ginebra en julio de 1951, obviando entonces la especialidad de la Convención de La Habana de 1928 y el Tratado sobre asilo suscrito en Montevideo en 1933, como las normas aplicadas al caso colombo peruano. Resulta una falsa expectativa hallar un debate sobre el Estatuto en América Latina durante la primera mitad del siglo $x x$ en relación con un caso de asilo político en su dimensión diplomáti$\mathrm{ca}$, si se tienen en cuenta las recientes consecuencias de la Segunda Guerra Mundial. En ese sentido es importante precisar que solo fue hasta los años ochenta, con ocasión de la crisis de América Central, que se amplió "la definición de refugiado a través de la Declaración de Cartagena sobre los Refugiados en 1984, permitiendo que más
Es decir, el refugio político obvió la existencia de un local revestido de inmunidad diplomática debido a su incapacidad para proveer resguardo colectivo y permanente ante un acto de urgente peligro para la integridad o la vida. En ese sentido, el asilo político-diplomático podría entenderse como una figura que recaía sobre personalidades célebres con cierto reconocimiento a sus posiciones políticas en contra de un régimen determinado, alejándose de aquella búsqueda que guía las migraciones y los desplazamientos humanos en el extranjero.

De otro lado, la importancia de hacer mención a este caso reside en que allí se concentraron la mayor parte de esfuerzos por confeccionar una narrativa que validara el carácter diplomático del asilo, destacando el cimiento en los tratados internacionales, y en el hondo sentir latinoamericano, legítimo e inmemorial. El éxito de este ejercicio redundó en la simplificación de un relato acontecimental que se encerró en un tipo de "prisión historiográfica", ${ }^{4}$ reproducida habi-

personas se incluyan dentro de este tipo de protección y no creando categorías subsidiarias. Lo mismo ocurrió en África durante el periodo de la descolonización, cuando se adoptó la Convención de la Organización de la Unidad Africana" (San Juan, 2003, pág. 44).

4 Este término se encuentra originalmente en la crítica formulada por el historiador Germán Colmenares a la forma irreflexiva en que se reprodujeron episodios contenidos en la obra de José Manuel Restrepo: Historia de la Revolución de la Nueva Granada (París, 1827). Su reclamo apunta a la simplificación de corregir y documentar sucesos que Restrepo narra bajo un sesgo ideológico, sin que se efectúe ningún tipo de confrontación. En palabras de Colmenares: "Aun para sus contradictores, la Historia de José Manuel Restrepo ha constituido hasta ahora un repertorio fijo e inalterable de los hechos, susceptible solo de reacomodarse en una interpretación diferente. Esta es una verdadera cárcel historiográfica que ha cerrado los caminos de la investigación a la infinitud de los hechos sociales" (1986, pág. 11) 
tualmente en las explicaciones que brindan los manuales ${ }^{5}$ y las lecciones de derecho.

En ese sentido, la genealogía del asilo político, más allá de constituir una extensa colección de sucesos involuntarios decantados a través del tiempo, tendió a exhibir un tipo de escritura anónima en la que se reforzaron imágenes con un alto contenido moral, donde resulta casi intuitivo pensar que el derecho nace desde aspiraciones buenas y justas, al punto que no existe una explicación sobre la naturaleza del asilo político que se encuentre desligada de un discurso en términos universales y valorativos.

La intencionalidad con la que el asilo político se escribió, también ha sido pasada por alto. La unidad discursiva y el alto grado de coherencia interna se han desvinculado de la voluntad de reinscribir, disuadir y aclarar lo que debe ser el pasado y la memoria, en buena medida porque esta inercia ha sido favorecida por los fuertes rasgos de linealidad, simplicidad, secuencialidad, heroísmo y esencialismo.

Por lo anterior, el presente texto no persigue analizar la dogmática del asilo político en su desarrollo consuetudinario o convencional, sino evidenciar la dimensión discursiva e histórica que encierra la literatura que predominó hasta mediados del siglo xx sobre él, sin perjuicio de que algunos aspectos sigan vigentes. Aunque en ella se privilegia el caso de asilo colombo peruano (Colombian Peruvian Asylum Case), Io

5 Entre los manuales más socorridos se pueden mencionar los de Zárate (2002), Ursúa (1952), Sanz de Santamaría (1978), Luque Ángel (1959), Bollini Shaw y Moreno Quintana (1950) y Yepes (1958). que aquí será objeto de estudio son los elementos comunes que concentran la mayor parte de las versiones sobre el surgimiento y la extendida práctica de una institución que pudo estar llamada al fracaso, destacando la intencionalidad de responder a un auditorio escéptico y distante, limitándome al sentido diplomático de esta institución.

\section{EL EXHORTO PARA CONSEGUIR APROBACIÓN}

La narrativa del asilo político se caracteriza por describir un conjunto de principios, casos y reglas que se orientan a demostrar la existencia de normas obligatorias extendidas y aceptadas en el ejercicio del derecho internacional. A través de ella, también se persigue remover las críticas mediante la exaltación y la apología, en busca de asegurar la adhesión del lector y del oyente.

A la voluntad de afirmar la preexistencia del asilo político le antecedieron agudos interrogantes como una práctica moralmente legítima. Por su parte, justificar un conglomerado discursivo de poder, respecto de las facultades que un Estado detenta a costa de derogar la soberanía extranjera, aislar impositivamente a un régimen político, explicar el inicio de una persecución penal en contra de un líder popular, normalizar a un disidente y su consecuente castigo, fueron estímulos que terminaron por confrontar dos grandes corrientes que rechazaban esta figura.

La primera, de corte eurocéntrico, cuestionaba la extraña ficción de prolongar los beneficios de 
la extraterritorialidad diplomática hacia las personas que no pertenecían a una misión como tal, además de constituir una práctica disonante con los principios jurídicos de los países avanzados o civilizados (Oppenheim, 1961, pág. 14; Ronning, 1965b, págs. 6-8, 20-22). A su vez, se consideraba que carecía de obligatoriedad porque no era más que un simple acto de cortesía estatal que podía retrotraerse si un perseguido representaba un peligro para la seguridad de otro país.

Por ejemplo, Lassa Francis Oppenheim (1961) explicaba en un texto guía de la Universidad de Cambridge, que el asilo político de ninguna manera era vinculante, en virtud a que no había "Ilegado a ser un 'principio general de derecho' reconocido por los Estados civilizados" y por tanto, no formaba parte "como tal, del Derecho Internacional" (págs. 248-249). ${ }^{6}$

La segunda crítica sobre el asilo político se orientó a visibilizar algunos riesgos dentro de la región. En esta línea, Simón Planas Suárez se destacó por denunciar la distancia entre la soberanía vista como un presupuesto esencial de

6 La dicotomía civilizado/incivilizado, presente en la literatura jurídica del siglo xIX, constituyó un elemento transversal en las explicaciones eurocéntricas que hacian referencia al asilo. Opiniones como las de Felice Morgenstern eran ampliamente conocidas. Para este autor el asilo era una excepción al derecho internacional, en la medida en que solo era practicado por países atrasados, que no eran civilizados completamente: "the fact that asylum is not exercised in the territory of leading states, and is mainly resorted to in the "backward" countries of the Near and Far [except Japan] East and of Latin America, suggests that it is a practice followed only states are not fully civilized in the Western sense of them, and as such it is a temporary exception to the system of international law which obtains in the community of civilized nations" (Morgenstern, citado por (Ronning, 1965b, pág. 21). Incluso desde los primeros estudios sobre el caso VRHT, se advertía que esta lectura, y puntualmente esta misma cita de Morgenstern, también era mayoritaria en la academia norteamericana; opuesta a la que en Latinoamérica se pretendía difundir (Evans, 1952, pág. 142). un Estado, y el rol que debe jugar el derecho en su protección.

Así se hubiesen ofrecido tesis más moderadas cuya propuesta buscaba que "el asilo debía concederse dentro de los límites de la prudencia, en forma que el derecho de asilo no causara desorden" (Cavelier, 1997, pág. 29), PlanasSuárez alertaba que a través de esta figura se podía menoscabar la autonomía, la jurisdicción territorial y la independencia política de las naciones libres. ${ }^{7}$ Como se verá, la imagen de la inestabilidad de los gobiernos que siguieron a las independencias, ${ }^{8}$ no siempre fue un recurso idóneo para promover el metarrelato en favor del asilo en su dimensión diplomática. ${ }^{9}$

7

Esta crítica que se fundaba en una noción rígida del concepto de soberanía, ha sido demoledora. Ni siquiera en las versiones oficiales más apologéticas se puede ocultar esta descripción: "la historia nos presenta en esta institución del asilo un símbolo de la impunidad que figuraba como viejo atributo de las soberanías: la guerra a los Estados y la protección a los culpables, constituyó realmente el culto de los pueblos antiguos" (Ministerio de Relaciones Exteriores, 1951, pág. 68).

8 "Factor esencial en el desarrollo del asilo en América Latina, ha sido la característica de esta de ser la tierra de los pronunciamientos y los golpes de fuerza para derrocar los gobiernos constituidos, es decir, su constante inestabilidad política. Esto ha llevado al mecanismo de asilo para la salvaguardia de los derechos humanos de los perseguidos políticos dado el desamparo en que quedan los miembros de los gobiernos derrocados y los militantes políticos en posición desfavorable" (Villa, 1992, pág. 104).

9 De acuerdo con Planas-Suárez: "el asilo diplomático no solo produce razonamientos y vejaciones que afectan la cooperación de los Estados y la armonía internacional, sino que su práctica ha sido y será fuente inagotable de dificultades y de daños morales, que únicamente pueden alimentar odios inextinguibles entre las naciones (...) La creación de un burladero para los pueblos, que otra cosa no es el asilo para los políticos en legaciones y embajadas, no se compadece en absoluto con el ideal republicano ni mucho menos con el sentimiento ingénito de un repúblico íntegro, adornado de valor cívico" (1953, págs. 272, 275). Es importante resaltar que este autor también incorpora los argumentos excluyentes eurocéntricos para justificar su posición política: "El problema que representan las repúblicas de la América latina a la vista de la humanidad civilizada es extremadamente grave. (...) Si el asilo diplomático es una práctica latinoamericana, —verdadera inverecundia - solo es merecedora de la execración de todas las naciones civilizadas y de los Estados donde la vida democrática es una realidad, no una ficción" (Planas-Suárez, 1953, págs. 266, 267). 
Incluso en las historias oficiales, el asilo daba indicios de ser una estrategia golpista. No es una casualidad que la narrativa aluda a la capacidad divisoria de esta figura. Esta preocupación quedó expresada como una huella emocional en la pluma de José Joaquín Caicedo Castilla, ${ }^{10}$ reproducida ampliamente hasta hoy, en manuales de derecho internacional (Monroy, 2002, pág. 636).

Teniendo en cuenta lo anterior, la vocación argumentativa que subyace a la literatura sobre esta institución coincide con dos líneas discursivas diferentes: a) responder a las críticas eurocéntricas, y b) morigerar la lectura sobre los riesgos y desventajas mediante la idea de que esta práctica era anterior a su positivización.

Sin embargo, ambas líneas reescriben el evento que radicalizó la mayor parte de los autores hacia 1949: la férrea oposición que manifestó el gobierno del presidente Manuel Odría, en contra de la protección que otorgó la embajada de

10 La explicación elaborada por este autor fue la siguiente: "el asilo ha sido reconocido en la América latina [sic] con un doble objeto: Primero, para proteger la vida, la libertad o la seguridad de personas perseguidas por delitos políticos. Esa persecución puede proceder no solo de una multitud enardecida, sino principalmente de las autoridades locales, tomándose esta expresión en un sentido amplio que comprenda los diversos órganos del poder público. (...) El asilo defiende a una persona perseguida cuyos méritos podrán más tarde ser reconocidos, permitiéndole prestar servicios eminentes a su patria y aun al continente. (...) El segundo objeto del asilo diplomático se relaciona con la aspiración que siempre ha existido en América Latina de asegurar el respeto de los derechos fundamentales del hombre (...) El asilo no se ha considerado en América latina [sic] como una forma de intervención. Porque jamás se ha aplicado en el sentido de que un gobierno pueda entrometerse en la política interna de un país, favoreciendo las personalidades de un determinado partido (...) El asilo no es, pues, contrario al principio de la no intervención, fundamental en el derecho americano, cuyo origen histórico debe señalarse en las relaciones entre Estados Unidos de América y las relaciones americanas. Porque estas lo reivindicaron como una afirmación de su independencia contra intervenciones que tuvieron lugar y que no es del caso volver a citar aquí" (Caicedo, 1961, págs. 299-300).
Colombia en Lima al líder de la Alianza Popular Revolucionaria Americana, Víctor Raúl Haya de la Torre, a comienzos de ese mismo año. ${ }^{11}$

De este giro se percibe no solo el aumento de las publicaciones sobre el asilo político, sino un creciente y abierto fomento a los procedimientos que garantizaran su ejercicio, bajo el supuesto de la preexistencia de un conjunto de reglas diáfanas sin las cuales no se podía aplicar esta institución de acuerdo con un particular contexto.

Precaver que estas resistencias fueron parte esencial de la narrativa permite entender el deseo de que se fortaleciera la noción sobre la naturaleza del asilo político, bajo un eje discursivo que privilegiaba un origen consuetudinario y convencional. ${ }^{12}$

11 Un relato sintetizado de la versión oficial la ofrece José Joaquín Caicedo Castilla. De acuerdo con este autor, el 14 de enero de 1949 el gobierno colombiano, a través del embajador Carlos Echeverri Cortés, solicitó la expedición de un salvoconducto, a fin de que Víctor Raúl Haya de la Torre (VRHT) salidera del país en calidad de asilado político. La concesión de este derecho se fundó en el artículo 2 de la Convención sobre Asilo Político, suscrita el 26 de diciembre de 1933. Con ocasión del asilo político efectuado el 3 de enero de ese mismo año, el gobierno de Perú presentó una respuesta el 22 de febrero, alegando Ios siguientes puntos: a) La Convención de Montevideo de 1933 no había sido ratificada por Perú. b) La calificación del asilado debía hacerse de común acuerdo por ambos Estados. c) El perseguido VRHT no cumplía con requisitos para una protección diplomática, dado que estaba acusado de graves actos "que envuelven una definida responsabilidad penal”. d) El gobierno de Perú no consideraba estar obligado a otorgar el salvoconducto (Caicedo, 1961, págs. 396-398).

12 "La institución del asilo, humanitaria en su esencia, tiene en América el valor que le confiere el acatamiento unánime de los pueblos de origen ibero y se halla consagrada por una práctica constante y uniforme, habiendo adquirido la fuerza obligatoria que emana de tratados solemnes libremente pactados" (Ministerio de Relaciones Exteriores, 1951, pág. 33). "Una ojeada ligera a la historia americana, desde la independencia hasta nuestros días, nos permite ver sucesos de carácter político que se han registrado y se registran en Latinoamérica que justifican ampliamente el Derecho de Asilo, mediante el cual una persona perseguida por un delito que no es común, logra ponerse a salvo refugiándose en la representación diplomática de cualquier de los Estados signatarios de las Convenciones sobre Asilo suscritas en La Habana y en Montevideo" (Ministerio de Relaciones Exteriores, 1951, pág. 111). 
En otras palabras, al reconocerse el espíritu intencional de refutar lo que se consideraba una especie de juicios civilizatorios y resistencias de gobiernos antidemocráticos, parece lógico que la narración romántica del asilo hubiera dado por sentado la existencia de una regla en el derecho internacional. ${ }^{13}$ Es decir, esta visión rescata el recurrente acto mecánico de mencionar el respeto habitual por parte de varios Estados que requerían o perseguían a un ciudadano sobre el cual recaía la protección diplomática, al punto de poder afirmar que se trataba de una práctica latinoamericana ampliamente aceptada.

Por lo anterior, es preciso matizar la afirmación sobre los usos y los significados derivados de la narrativa del asilo político como una reacción exclusiva para doblegar la voluntad del gobierno peruano, dada su posición como Estado territorial, en el caso Víctor Raúl Haya de la Torre. El cuidado inicial de la literatura jurídica de media-

13 Es importante resaltar que este origen legítimo fundado en la tradición y en la costumbre, era primeramente el producto de una íntima convicción aceptada y tolerada entre diferentes pueblos occidentales. Prueba de ello era que dichas prácticas, a base de ser observadas, habían llegado a convertirse en derecho positivo a través de un proceso de codificación concertado (Monroy, 2002, pág. 88). Al respecto, a continuación se cita un fragmento de la nota de la Cancillería de EI Salvador, de fecha 17 de noviembre de 1950, dirigida al secretario de la Corte Internacional de Justicia, Eduardo Hambro, suscrita por Roberto E. Canessa, ministro de Relaciones Exteriores de dicho páis: "EI gobierno salvadoreño estima que está fuera de duda que la costumbre es fuente de derecho internacional, y considera que el principio del asilo es una regla de conducta obligatoria, que está arraigada en lo más hondo del sentimiento latinoamericano. Considera que dicho principio que es válido y que es justo, por lo que continuamente se ha aplicado en casi todos los países de América, constituyendo un axioma fundamental de sus sistemas jurídicos. Estima que es una "norma de cultura", una conciencia jurídica, un derecho "sentido y vivido", al cual se ha reconocido su validez intrínseca y se le ha dado general cumplimiento. (...) La costumbre debe tenerse en cuenta, cree mi gobierno, máxime cuando sus fundamentos han sido incorporados en convenios internacionales, como en el suscrito en La Habana en el año de 1928 por las Naciones americanas, y la Convención sobre asilo político de Montevideo, firmada en 1933" (Ministerio de Relaciones Exteriores, 1951, pág. 68). dos del siglo xx se orientó a maquillar la estirpe periférica del asilo, naturalizando el mensaje que impugnaba las voces europeas excluyentes, que se resistían a aceptar que el derecho internacional había reconocido y sancionado efectivamente esta institución.

El otro reto fue asumir la debilidad y la novedad de la figura en el derecho y las relaciones internacionales. De acuerdo con la investigación de C. Neal Ronning (1965b) el asilo en Latinoamérica no siempre fue el fruto del cumplimiento de una regla que hubiese sido admitida como obligatoria entre los Estados. Luego de documentar varios casos este autor halló serios vacíos en la costumbre y en los tratados internacionales, notando que la justificación para otorgarlos se había fundado en conveniencias políticas, las cuales eran extrañas a cualquier tipo de regla concreta (págs. 214-216), y mostró que en la práctica los Estados territoriales latinoamericanos no siempre se habían resistido a que el perseguido gozara de protección diplomática (pág. 45).

Por ende, no en todos los casos habían surgido controversias en torno a su concesión, que derivaran en discusiones jurídicas sobre el fundamento de su exigencia, o la necesidad expresa de contar con un procedimiento claramente definido (Ronning, 1965b, pág. 66). En consecuencia, al haber sido tolerado o consentido tácitamente, la peligrosidad del asilado no fue un aspecto sustancial para su aplicación, ni tampoco una carga para el Estado territorial (Ronning, 1965b, págs. 46-47). 
En ese sentido, los aportes de Ronning son valiosos porque muestran que el proceso de construcción del discurso jurídico en torno al asilo sufrió vacíos, contradicciones y desaprobaciones. Es decir, que no existió siempre una idea unívoca sobre esta institución jurídica, y que tampoco fue el fruto espontáneo de las buenas semillas de Occidente.

Sin embargo, no deja de ser notorio que Ronning al indagar sobre la tesis del asilo político, en particular, como una institución sancionada por el derecho internacional, sopesa nuevamente la evidencia que los magistrados de la Corte Internacional de Justicia tuvieron en cuenta en el fallo del 20 de noviembre de 1950 para rechazar esta institución, ${ }^{14}$ contrastándola con otros documentos.

\section{A. Influencia de la historiografía hispanoamericana del siglo XIX}

La lógica del exhorto por conseguir la aprobación del lector se nutre de movilizar finalidades discursivas internas, no visibles, a través de un lenguaje narrativo que coincide ampliamente

14 "The facts brought to the knwoledge of the Court disclose so much uncertainty and contradiction so much fluctuation and discrepancy in the exercise of diplomatic asylum and in the official views expressed on various occasions, there has been so much inconsistency in the rapid succession of conventions on asylum, ratified by some States and rejected by others, and the practice has been so much influenced by considerations of political expediency in the various cases, that it is not posible to discern in all this any constant and uniform usage, accepted as law, with regard to the alleged rule of unilateral and definitive qualification of the offence. The Court cannot therefore find that the Colombian Goverment has proved the existence of such a custom (...) For these reasons, the Court has arrived at the conclusion that Colombia, as the State granting asylum, is not competent to qualify the offence by unilateral and definitive decision, binding on Peru" (Colombian-Peruvian asylum case, Judgment of November 20th, 1950: International Court of Justice. Reports 1950, 277-278). con los rasgos característicos de la historiografía hispanoamericana del temprano periodo poscolonial. ${ }^{15}$ Se trata de referencias a personajes anónimos en forma de "héroes de bronce" que se destacan por su carácter noble y gallardo, sin dejar de prescindir de un pasado hispanista. ${ }^{16}$

15 Una prueba de ese elemento es que el referente bolivariano fue notorio en la política interna de Colombia de mediados de siglo. El proyecto cultural del laureanismo y del conservatismo buscó, a la usanza de la tradición regeneradora, volver a establecer los tres pilares clásicos de fines del siglo xIx: el catolicismo, el hispanismo y el pensamiento del Libertador. Basta señalar que una estrategia para adelantar este último proyecto fue la publicación de medios de difusión, como la célebre Revista Bolívar (González, 2012, pág. 376). Autores como Jesús María Yepes compartían esta opinión. Se puede citar, a propósito, su discurso de posesión como miembro de número de la Academia Colombiana de Jurisprudencia, en 1956, en el que exhortaba a formular una política exterior acorde con un pasado decimonónico de próceres eximios como Bolívar, Santander, Pedro Gual, Francisco Antonio Zea y otros; que se compadeciera con un origen puro y correcto por definición, afín con la edad de oro de "nuestra diplomacia"; equivalente a una historia de bronce (1822 a 1826): "Sin tradición —como noblezaobliga Colombia tiene el deber de formular hoy su política internacional en términos que no bastardeen de esos gloriosos antecedentes. Necesitamos que el hemisferio occidental vuelva a ver a los colombianos de hogaño [sic] sabemos pensar continentalmente —como Bolívar y como Suárez-, y que no somos en manera alguna indignos de los varones egregios que antaño fueron prez y honra de nuestra América (...) la historia nos exige que retomemos a los hontanares de nuestra diplomacia" (Yepes, 1956, págs. 12-13).

Adentrado el siglo xx la afiliación con España continuó siendo el vehículo legitimador para promover el asilo político como una contribución a la modernidad. Una forma de reconocer el hispanismo fue sacralizando de alguna manera el castellano. Para Malcolm Deas la preocupación por el idioma en José Manuel Marroquín, Rufino José Cuervo y José María Vergara y Vergara: "radicaba en que la lengua permitía la conexión con el pasado español, lo que definía la clase de república que estos humanistas querían. (...) La gramática, el dominio de las leyes y de los misterios de la lengua, era componente muy importante de la hegemonía conservadora que duró de 1885 hasta 1930, y cuyos efectos persistieron hasta tiempos mucho más recientes" (2006, págs. 30,48$)$. La relación que advierte este autor entre gramática y poder, la explica particularmente en el pensamiento de Miguel Antonio Caro como representante de una clase dependiente del gobierno, heredero de la antigua burocracia del imperio español, acostumbrado al poder político, a quien "No le parecía, en lo más mínimo, anormal o inverosímil que este fuera ejercido por letrados, como muchos de sus miembros, cuyos antepasados habían venido a las Américas a gobernar a cualquier título. Para los letrados, para los burócratas, el idioma, el idioma correcto, es parte significativa del gobierno. La burocracia imperial española fue una de las más imponentes que el mundo jamás haya visto, y no es sorprendente que los descendientes de esos burócratas no lo olvidaran; por eso, para ellos lenguaje y poder deberían permanecer inseparables" (Deas, 2006, págs. 30, 43). 
Es importante mencionar en este punto que existe una convergencia entre la forma en que se han narrado los antecedentes del asilo político y las observaciones formuladas por el historiador Germán Colmenares a estas historiografías. ${ }^{17}$ Primero, que las imágenes casi figurativas, alegóricas o simbólicas que se han construido sobre esta institución, son en gran medida reproducciones que se han cifrado como parte de una historia nacional o una historia patria, de origen latinoamericano. Segundo, que en la narrativa del asilo político no figura un autor o un momento creador, puesto que se ha tratado de exaltar la idea de una práctica inmemorial (Ronning, 1965a, pág. 131), lo cual indica que "la fuerza misma de dichas imágenes reside en su carácter aparentemente anónimo, como si se tratara de la elaboración espontánea de un inconsciente colectivo" (Colmenares, 1987, pág. 12).

De otra parte, la alusión a la genealogía del asilo político se asemeja a las primeras versiones de la Independencia. ${ }^{18}$ Ambas referencias ac-

17 "El presente en Hispanoamérica no es prisionero del pasado sino más bien de las imágenes construidas del pasado. Hace falta algo más que un desdén perentorio para exorcizarlas: hay que comenzar por interrogarlas seriamente y por examinar los mecanismos de su producción y su razón de ser" (Colmenares, 1987, pág. 23).

18 "La institución del asilo tiene una significación muy importante en la América Latina. Se concibió fundamentalmente ante la frecuencia de las perturbaciones políticas y la necesidad de proteger la vida, la libertad y la seguridad de las personas perseguidas por delitos políticos" (Gaviria, 1988, pág. 229). "No hay que negar que este derecho ha sido mejor practicado en los países de América Latina que en Europa. Existe pues una marcada referencia de opinión, en cuanto al origen de esta tradición, entre los internacionalistas de los dos continentes; los unos lo entienden en el carácter hospitalario y los sentimientos elevados de estos pueblos; los otros lo atribuyen más a la frecuencia de las revoluciones y a los cambios de gobierno en estos países, que tienen por causa la opresión de las clases más desvalidas" (Zárate, 2002, pág. 39). túan de alguna manera como los guardianes de un cuerpo de creencias que ejercían la función pública de preservar y "restaurar fragmentos del pasado que de otra manera se hubieran perdido irremediablemente" (Colmenares, 1987, pág. 22). ${ }^{19}$

La importancia de contar los antecedentes del asilo en un lenguaje superficial, homogéneo y unívoco, oculta cualquier tipo de lucha étnica o social, incluyendo los debates que recaen sobre conceder el asilo a los militares o no. De ahí que en los manuales de derecho internacional se admitan y se presenten acontecimientos como intuitivos, involuntarios y sin control (Gaviria, 1988; Monroy, 2002; Seara, 1982). Como si América estuviera marcada por el destino de ser el nuevo horizonte que da a luz prístinas instituciones humanitarias (Colmenares, 1987, págs. 197-202).

\section{B. La visión naturalista}

La literatura que aborda el asilo político es el resultado de insistir en una práctica proveniente del pasado que funda su existencia. Para ello la narrativa del asilo se caracteriza por emplear una técnica de escritura que consiste en adoptar "una gran narración" universal, guiada por una visión naturalista del derecho internacional

19 "Ello no era un impedimento para que se atribuyeran a sí mismos una función condescendiente como educadores de las masas o como profetas de un futuro acomodado en su propio provecho (...) Muchos habían presenciado o se sentían herederos inmediatos de una revolución que parecía ponerlos en posesión de la historia, de sus mecanismos de cambio político y social. Eran los primeros en llegar a un territorio en donde la experimentación parecía ilimitada. Su preferencia por el periodo de la revolución no hace sino indicar hasta qué punto sentían que debían aprovechar esta ventaja" (Colmenares, 1987, págs. 1820). 
(Becker, 2006). Se trata de un metarrelato que intenta explicar la procedencia del asilo político y la forma en que se integra a la tradición jurídica occidental. Esta técnica refuerza el anonimato del autor al tiempo que omite mostrar los intereses del argumento jurídico.

La visión naturalista en la narrativa del asilo asume la preexistencia de un conjunto de coincidencias que familiariza el auditorio latinoamericano con el europeo. La idea está vinculada a promocionar y expandir los valores de la civilización occidental. La visión naturalista no fue contraria a enfatizar que la actividad jurídica americana participaba en la tarea del destino manifiesto encomendada al derecho internacional en los territorios del Nuevo Mundo (Obregón, 2006a, pág. 255).

A partir del uso de esta lectura, es posible afirmar que la narrativa del asilo también resulta ser coherente con la búsqueda constante de una referencia europea que daba norte a una idea de nación de corte decimonónico, así como del derecho internacional eurocéntrico. Esto radica en el predominio de los cánones jurídicos europeos para predisponer el lenguaje empleado en los debates de este tiempo en términos de civilidad y progreso (Obregón, 2012, pág. 924).

No obstante, es a partir de la lectura que exacerba la animadversión por el gobierno peruano que se prolifera la visión obsesiva y radical por contar y rectificar aquellos acontecimientos que nutren el metarrelato. La voluntad de disuadir se advierte al narrar una práctica histórica, legítima y sagrada en su origen, la cual data de los templos de la antigua Grecia. De acuerdo con esta perspectiva, el carácter religioso es heredado por el Imperio romano. Y luego por el Cristianismo a través de la concepción de que las iglesias son inviolables. ${ }^{20}$

Posteriormente, se procede a enunciar una breve relación de casos que indican cierto consentimiento y tolerancia de las grandes potencias hacia esta práctica. ${ }^{21}$ Para autores como Enrique Gaviria Liévano, Guillermo Villa Alzate y Germán Cavelier, la aspiración legitimadora en ningún caso será ajena al territorio europeo.

El relato que da cuenta del asilo político incorpora a su vez unidades temporales. Dichas unidades acentúan el ocaso de un microperiodo, seguido por el florecimiento de uno más próspero.

20 "Hemos visto que el asilo es una institución que se remonta a la época de Grecia antigua, en donde se concedía refugio en los templos sagrados. Pero andando el tiempo, de una institución eminentemente religiosa se pasa a una de carácter político y jurídico" (Gaviria, 1988, pág. 229). A diferencia de Gaviria, Guillermo Villa Alzate incluye el siguiente aporte del derecho romano: "Pero el verdadero proceso de depuración del derecho de asilo, el que le imprime un carácter más jurídico y lo dota de más seriedad, comienza con la conquista romana en territorio griego. Roma humanizó este derecho, haciendo reposar su razón de ser en el respeto al príncipe y lo sustrajo del respeto a la divinidad" (1992, pág. 104). "En la antigua Grecia el asilo era un refugio inviolable para las personas perseguidas que buscaban protección, y en sentido general todos los templos y altares eran inviolables. Este carácter religioso del asilo se trasladó a las iglesias con el advenimiento del Cristianismo, mas desapareció en la época generalmente llamada moderna" (Cavelier, 1997, pág. 11). "In the naturalistic mode, universality is a necessary attribute of the law of peoples. (...) Thus, a portrait of relationships between autonomous political entities during ancient times or belonging to non-Western civilization as being regulated by norms analogous to or preceding modern international law becomes concrete evidence of universality" (Becker, 2006, pág. 291).

21 "A tiempo que se desarrollaba la teoría y la práctica de la extradición, Europa también conoció casos de asilo interno, desde el famoso concedido en 1726 al duque de Riperda en la Embajada británica en Madrid, que llegó a comprometer las relaciones de Gran Bretaña con España. Así mismo Inglaterra amparó a los israelitas de la persecución en Grecia en 1867. En 1873 el mariscal Serrano se refugió en la legación inglesa en Madrid, y en 1985 Said Pasha en la de Constantinopla" (Cavelier, 1997, pág. 13). 
Es en este movimiento de continua perfección donde la creación y el ingenio tienen cierta cabida. Solo en un lugar de tales características se menciona el territorio de América, no como un lugar geográfico, sino como el gran referente cultural que vitaliza y comunica lo viejo con lo nuevo, el pasado con el presente.

Entre la mención de Europa y América, se procede a añadir la aparición de dos prácticas intermedias que son previas al nacimiento del asilo político con un giro superficial y algo abrupto. Inicialmente, el asilo territorial, y posteriormente, el asilo interno. El primero se concedía a los criminales comunes, el segundo a aquellos que buscaban protección "en el local ocupado por el representante de un Estado extranjero" (Cavelier, 1997, pág. 13).

Siguiendo una línea cronológica, la variación que sobreviene a una lectura política y característicamente americana ${ }^{22}$ consiste en enfatizar, por una parte, los efectos de las luchas sobrevinientes a la independencia, pero al mismo tiempo, las dificultades para la concesión del asilo territorial, en razón a las grandes distancias entre los países. Se aclara que la generalidad no era que se concedieran asilos territoriales, "a menos que las fronteras estuvieran cercanas al lugar de los trastornos políticos" (Cavelier, 1997, pág. 4).

"Hoy se distinguen dos clases de asilo: el territorial y el político o diplomático. El primero se concede a los perseguidos por delitos políticos para que se refugien en un Estado diferente del de su nacionalidad. En cambio el político o diplomático se concede en el propio territorio en donde se persigue a una persona acusada por delitos políticos y se le otorga refugio en una embajada, legación u otro sitio señalado por las convenciones internacionales sobre la materia. El asilo diplomático se considera como una de las instituciones propias del llamado derecho internacional americano" (Gaviria, 1988, pág. 229).
Sin embargo, la narración vuelca la memoria sobre el asilo hacia los recurrentes y socorridos golpes militares, antes de cualquier formalización en los tratados interamericanos. Esta visión privilegia a los actores castrenses del siglo XIx que, sin proponérselo, le terminan dando un soplo de vida a la institución. Es como si ellos fueran los continuadores de un largo recorrido que inició en la antigua Grecia pagana, y llegó hasta el Nuevo Reino de Granada (Cavelier, 1997, págs. 16-21).

La lucha consustancial a la inestabilidad política aparece equilibrada por el orden que brinda una institución que surge por los vaivenes propios de la realidad latinoamericana. En ese sentido, las nociones de naturaleza, guerra e identidad se funden en la práctica del asilo como una unidad que atraviesa la vida $y$, consecuencialmente, el derecho.

Adicionalmente, es importante mencionar la porosidad como un rasgo central al resaltar el concepto de frontera. No es posible que el lector logre diferenciar en la narración, cuándo se le refiere a una postura asumida por una nación, de una que abarca el orden continental. Se admite que en Colombia y en el resto de Latinoamérica se experimentó lo mismo. De hecho, si se llegara a analizar un lugar específico en cualquier parte del continente, no habría posibilidad de hallar alteraciones porque los hechos del pasado conducen a la misma práctica, siempre de manera indistinta e invariable.

El recurso de crear un efecto aglutinante de voces, experiencias y opiniones de países diferen- 
tes, apunta a que se enuncien múltiples semejanzas, ambientadas por un aura de ingenuidad, las cuales ratifican la solidez de la identidad americana como un coro que entona el mismo himno continental. Es como si el interlocutor en una conversación dijera: - ¡Créeme, fue así, todos nosotros no estamos equivocados! Se trata de un esfuerzo por homogeneizar la opinión latinoamericana, de modo que se deja suspendida en el tiempo la experiencia europea. El perfeccionamiento del derecho internacional queda ya en el hogar de América Latina como efecto del olvido o la amnesia repentina que ha sufrido el Viejo Mundo.

\section{Humanismo y temporalidad}

Un aspecto trascendental en el metarrelato del asilo político es la referencia permanente del amparo como un acto frecuente y humanitario. El asilo como el refugio brindado por los pueblos antiguos a los perseguidos en lugares sagrados, se entremezcla rápidamente con la importancia de garantizar la vida de quien corre peligro, como una especie de derecho que ha estado presente en todas las sociedades civilizadas.

Lo que más se resalta aquí es, primero, su contenido religioso; ${ }^{23}$ segundo, la idea de que el asilo es una costumbre inmemorial que antecede a cualquier norma positiva; y tercero, que el asilo es equivalente al derecho natural de legítima

23 "Su origen se remonta a la época más floreciente de la civilización griega, en la cual el privilegio del asilo se ejercía en los templos, altares, monumentos erigidos a los dioses en mausoleos, etc. El carácter íntimamente humanitario del asilo hizo que el cristianismo lo adoptase, no obstante su origen pagano. Durante toda la Edad Media, el asilo fue privilegio de las iglesias" (Zárate, 2002, pág. 9). defensa, el cual precede igualmente al nacimiento del Estado. ${ }^{24}$

Aun cuando se advierte la presencia de una noción de progreso histórico en la explicación de los antecedentes del asilo, es Ilamativo que se ignore tanto la pureza como la originalidad europea en el derecho internacional. La aparición de América como un eslabón más de la cadena del derecho natural-universal, busca fundamentalmente resaltar las similitudes entre las sociedades "occidentales-civilizadas", que datan incluso desde la Edad Antigua. La razón de ello radica en que las comunidades siempre habrían estado gobernadas por los mismos principios; de modo que no es posible establecer momentos o acontecimientos fundacionales, o moldeadores del origen de esta institución (Becker, 2006, pág. 291).

Este tipo de afiliación a una tradición consuetudinaria, de acuerdo con Arnulf Becker Lorca, depende más del uso de una narrativa histórica capaz de apropiarse de un linaje naturalista. Dicho empleo le da continuidad al pasado. Por ende, se trata de reconocer la idea que el derecho y los principios son inmanentes a las sociedades y, en consecuencia, no surgen o se derivan de observar la relación entre los pueblos a lo largo del tiempo (Becker, 2006, pág. 291).

24 "Al defender a un refugiado político, Colombia defiende un derecho fundamental de la persona humana, y honra no solo las obligaciones contractuales sino a los compromisos de otro orden, cuya fuerza nadie sería osado a desconocer" (Caicedo, 1974, págs. 427-428). "El asilo para protegerse contra persecuciones injustas es un derecho natural del hombre anterior y superior al Estado mismo. El derecho de asilo es en su origen una emanación inmediata del derecho de legítima defensa que el Estado no puede desconocer en el individuo. Por eso tal derecho tiene una existencia varias veces milenaria" (Zárate, 2002, pág. 9). 
Finalmente, el concepto de tiempo que emplea la evolución del asilo -indistintamente de que acoja una lectura naturalista-, coincide con una narración de progreso en la que se transmite la expansión del éxito o el perfeccionamiento del derecho internacional, en el curso de grandes hitos europeos. ${ }^{25}$ La temporalidad lineal -0 de calendario-, solo es un eje para ubicar secuencialmente gérmenes y virtudes que van dando forma a la institución, donde no hay lugar al retroceso, la ruptura o la discontinuidad.

De este modo la narrativa del asilo exhibe cierto optimismo por lograr incorporarse a un gran proyecto civilizador. Oliver Diggelmann sostiene que una particularidad de estas narrativas radica en la mayor relevancia que empiezan a tener los intereses colectivos de la "comunidad mundial", a pesar del tradicional dominio de los Estados (2012, pág. 1008).

\section{LA VOLUNTAD DE RECTIFICAR LOS ACONTECIMIENTOS}

\section{A. La escritura oficial del asilo político}

Cuatro décadas atrás Caicedo (1974) escribió una obra guiado por un fin muy ambicioso: "relatar el desarrollo de la política internacional de Colombia en sus diversos aspectos, a partir de la Independencia hasta los momentos actuales"

25 Según Diggelmann (2012, pág. 1002), estos tres periodos convencionales son: Paz de Westfalia y guerras napoleónicas (1648-1815), Congreso de Viena y la Primera Guerra Mundial (1815-1914), y el periodo entre guerras mundiales (1919-1939).
(1974, pág. 17). En ella enfatizaba al lector que tenía en sus manos, "una visión completa y de conjunto", caracterizada además por la forma de exposición imparcial y objetiva (pág. 17).

Caicedo buscaba enunciar de manera exacta los hechos y precisar los conceptos acudiendo a la síntesis; quería resaltar que esta explicación contenía "cuestiones en las cuales van envueltas nobles, altas y respetables nociones de patriotismo, de dignidad nacional y de defensa de los derechos o intereses de los diferentes Estados" (1974, pág. 18). Siguiendo su expresa aspiración de imparcialidad y objetividad, advertía este autor que su trabajo le había permitido descubrir un resultado, que seguramente desconocía:

Además es grato comprobar que de todas estas gratas historias resulta y se deduce, sin lugar a dudas, que la política internacional colombiana ha brillado, a través de los tiempos, por su buena fe, honestidad, adhesión al derecho, y respeto a la comunidad internacional y a las otras naciones soberanas. Ha sido siempre una política exterior siempre leal, recta y justiciera (Caicedo, 1974, pág. 18).

Es posible pensar que Caicedo acudía a la historia imparcial y objetiva, como el que sueña traer "la voz misma del pasado reflejada en lo contemporáneo" (Febvre, 1974, págs. 32-34), pero la objetividad y la imparcialidad era temor. Sentía que si confesaba que había escogido simplemente lo que necesitaba del tiempo, podía ser censurado. El estudio de lo social y lo humano, como un objeto central de la historia, era desconocido en su momento. Los hechos 
no eran producto del hombre, ${ }^{26}$ eran antes que nada, eso, hechos que podían ser disecados, tal cual como ocurrieron. Por tanto, se pasaban por alto las pasiones, las ambiciones y los miedos de los actores del pasado, y la de quienes los interpretaron, los organizaron y los reconstruyeron en un momento posterior. ${ }^{27}$ La historia tenía la función social de reafirmar los valores de la Patria y el Estado. ${ }^{28}$

Pero el punto más importante, más allá del escrúpulo y el silencio que trae la intencionalidad de la historia, es la convergencia de dos corrientes que beneficiaron una técnica de escritura incólume hasta el presente. Para ello hubo dos grandes motores. Primero, la disputa para abrir un espacio en el universalismo del derecho natural. Segundo, el abismo que habita entre el derecho y la esfera social de la historia.

Ambos sirvieron para afianzar la des-concatenación especial en la que se encuentran sumergi-

26 "La historia es ciencia del hombre, y también de los hechos, sí. Pero de los hechos humanos. La tarea del historiador: volver a encontrar a los hombres que han vivido los hechos y a los que, más tarde, se alojaron en ellos para interpretarlos en cada caso" (Febvre, 1974, pág. 29).

27 "El hombre no se acuerda del pasado; siempre lo reconstruye. El hombre aislado es una abstracción. La realidad es el hombre en grupo. Y el hombre no conserva en su memoria el pasado de la misma forma en que los hielos del Norte conservan congelados los mamuts milenarios. (...) La historia objetiva interpreta, organiza. Reconstruye y completa las respuestas. Se hace el pasado que necesita. $Y$ en ello no hay escándalo ni atentado contra la supuesta majestad de la ciencia. (Febvre, 1974, págs. 32-34).

28 "La construcción de una conciencia histórica pasa a través de la ecuación pasado/presente. "Es en función de sus necesidades presentes —escribió L. Febvre - que la historia recoge sistemáticamente, que clasifica y agrupa los hechos pasados. Es en función de la vida que se interroga la muerte: organizar el pasado en función del presente es lo que podríamos denominar la función social de la historia". El binomio pasado/presente es una forma de diálogo dialéctico en el pensamiento histórico" (Fazio, 1991, págs. 35-51). das las narraciones jurídicas latinoamericanas (Villegas del Castillo, 2009, págs. 18-19), de la cual la narrativa del asilo político no ha sido ajena. Esta situación recurrente se evidencia a través de una estructura que acertadamente describió Catalina Villegas del Castillo, así:

Los historiadores del derecho cometen el siguiente error: inician sus trabajos con un capítulo introductorio al que denominan "contexto histórico, económico, político y social" (o capítulo introductorio de contexto) basado en la descripción de hechos ocurridos en un momento determinado y a continuación relacionan un segundo capítulo en el que se dedican al estudio específico del tema sin vincularlo con los aspectos que desarrollan en el acápite introductorio (2009, pág. 18). ${ }^{29}$

Es preciso señalar que la des-concatenación especial se acentuó a partir de las obras que se dedican a examinar los despropósitos de los pronunciamientos de la Corte Internacional de Justicia en el caso de Víctor Raúl Haya de la Torre. En ellas se evidencia una desconexión entre las explicaciones históricas o culturales, y el pri-

29 Por ejemplo, la tesis para optar al grado de doctor en Ciencias Jurídicas de la Universidad Nacional de Colombia, titulada "El asilo en el derecho internacional americano" escrita por Luis Carlos Zárate en 1953, y citada frecuentemente en este texto, contiene una explicación sobre el origen del derecho de asilo, que se remonta a los tiempos bíblicos abarcando largos periodos de "historia universal". El capítulo I. Origen del derecho de asilo, ubicado en la primera parte del libro, y el capítulo III. Evolución del derecho de asilo en América, situado en la segunda parte, no dejan ver por sí mismos los elementos del contexto social, político o económico, que contribuyan a explicar el interés de Colombia en defender fervientemente el derecho de asilo, más allá de respetar la tradición y los tratados. Zárate (2002) afirma lo siguiente: "Vemos así cómo los antiguos hebreos tenían destinados para el asilo seis ciudades: Bezer, Rmoth, Galán, cuyos privilegios fueron establecidos por el propio Moisés, y Kudesh, Bichm y Hebrón, que por mandato suyo se fundaron después de su muerte" (pág. 20). Sin embargo, entre los trabajos historicistas ortodoxos sobre el derecho de asilo se destaca el de Garzón Cortés (1982) y más recientemente el de Villa (1992, págs. 103-116). 
vilegio de detallar en buena parte las abundantes vicisitudes procesales.

Pareciera entonces que los antecedentes y el asilo político propiamente dicho fueron momentos que estuvieron marcados por el antes y el después del ingreso de Víctor Raúl Haya de la Torre a la embajada de Colombia en Lima, en la madrugada del 3 de enero de 1949. ${ }^{30}$

Sin embargo, tanto la influencia de la Escuela Histórica del Derecho como del historicismo legal en el campo jurídico, a partir de la obra

30 El texto que más se destaca en este sentido es: El asilo diplomático. Comentarios sobre la sentencia de la Corte Internacional de Justicia en el asunto concedido en la Embajada de Colombia en Lima al Dr. Víctor Raúl Haya de la Torre, escrito por Francisco A. Ursúa y publicado en 1952. La obra se halla organizada secuencialmente: antecedentes de la demanda, la demanda, el juicio, las pruebas; el debate en torno a la calificación del delito y la obligación de expedir salvoconducto; la necesidad y duración del asilo; y finalmente la respectiva sentencia. Su objetivo apuntaba a efectuar un análisis hermenéutico poniendo de presente la incompatibilidad entre el derecho internacional americano y las interpretaciones de la Corte. Sobre la declaración de que el asilo se ejerció lejos de toda reglamentación definida, sostiene: "La Corte Internacional de Justicia habría hecho bien en interpretar en este sentido la realidad americana, a fin de contribuir al desarrollo, definición y perfeccionamiento de esas normas incuestionablemente de derecho, en vez de intentar despojarlas de este carácter para abolir de una plumada siglo y medio de evolución jurídica de un continente" (Ursúa, 1952, pág. 215). Un ejemplo de la des-concatenación especial se puede encontrar de nuevo en Caicedo, cuando reconstruye el derecho de asilo en dos partes separadas. Un primer momento ocurrido en la Cancillería y el cuerpo diplomático residente en Bogotá hacia 1885, que se deriva de la siguiente situación: un individuo "a quien por causas políticas se impuso una contribución de guerra, se refugió en la legación de la Argentina. Además otras personas de la oposición se asilaron en varias representaciones diplomáticas". Se procede a citar de forma escueta las posiciones de los ministros de Chile, Alemania, Estados Unidos, Gran Bretaña, Francia e Italia. Al final se llega a la conclusión que los diplomáticos no admitieron "posibilidad alguna de que les suprimieran sus inmunidades, cualesquiera fuesen sus opiniones tratándose de asilo a delincuentes políticos" (Caicedo, 1974, págs. 370-371). Luego, unas páginas más adelante, en el capítulo XXXIX se dedica exclusivamente al caso Haya de la Torre, y se puede percibir la influencia de las obras en torno a las vicisitudes procesales, dado que su estructura es casi idéntica: los hechos, las tesis peruanas y colombianas, el contenido de la demanda presentada por la CIJ, contenido y características de la sentencia, modificaciones del procedimiento, peticiones elevadas por las partes y la consecuente solución del conflicto (Caicedo, 1974, págs. 409-428). de Karl Friedrich von Savigny, han empezado a ser un punto de partida en los nuevos acercamientos que desconfían de las historias románticas y progresistas de las instituciones jurídicas tradicionales. ${ }^{31}$

\section{B. La lectura secular}

El cambio que sufrió la narrativa del asilo político en 1949, concomitante al caso Víctor Raúl Haya de la Torre, también incorporó la lectura secular del derecho internacional, consistente en la capacidad que tenían los abogados internacionalistas de proveer una legislación positiva, a raíz de un proceso de codificación que se

31 En ese sentido, una obra que se destaca por efectuar una revisión juiciosa de los presupuestos en la escritura de la historia del derecho historizante, es la tesis doctoral de Isabel Cristina Jaramillo Sierra, cuya versión en español se publicó en 2013 con el título: Derecho y familia en Colombia. Historias de raza, género y propiedad (1540-1980). En ella es importante el empleo de la noción del derecho como "campo de batalla". En palabras de la autora: "La idea del derecho como campo de batalla tiene que ver con la concepción de las relaciones sociales como relaciones de conflicto y, en ese sentido, abrazarla implica aceptar que el derecho juega un papel en la determinación de los recursos que están en juego en una situación, en las jugadas que se consideren posibles y en los individuos que pueden enfrentarse o quedan excluidas" (Jaramillo, 2013, pág. 15). Ser consciente de este aspecto es relevante porque permite entender que la literatura jurídica, -lo cual es aplicable al caso del asilo político-, puede constituir "un mecanismo de distribución de recursos, creación de identidades y legitimación o naturalización de los procesos históricos por los que esto ocurre" (Jaramillo, 2013, pág. 15). Por su parte, La invención del derecho privado, escrita por Monateri y Samuel (2006), es un estudio que emplea un enfoque análogo. Una de las reflexiones más importantes de este texto es el impacto que una genealogía histórica-jurídica puede tener sobre las estructuras de gobierno y en la distribución del poder. El objetivo de Monateri y Samuel es claro cuando se trazan lo siguiente: "quiero mostrar que la teoría, generalmente aceptada, de que la conciencia jurídica occidental se encuentra históricamente asentada sobre fundamentos derivados del derecho romano, concebido como la descendencia original del espíritu humano, es de hecho producto de proyectos de gobernabilidad con fuertes implicaciones prácticas" (2006, pág. 103). Tampoco se puede descuidar el agudo estudio preliminar propuesto por Carlos Morales de Setién Ravina, cuyos pasajes demuestran una adaptación de las reflexiones de Michel Foucault en relación con una visión del derecho en términos de una "práctica discursiva" que puede hacer variar la realidad en un sentido deliberado (Monateri y Samuel, 2006, pág. 103). 
había iniciado durante las conferencias americanas (Caicedo, 1974, págs. 381-407). ${ }^{32}$

El caso Haya de la Torre es una etapa importante en la evolución de la narrativa del asilo político, en la medida que condensa parte del lenguaje jurídico criollo proveniente del siglo xIX. A partir de la década de 1950 se tomará como el referente de la herencia de la civilización y el cristianismo, ${ }^{33}$ en la que además se cristaliza una larga tradición consuetudinaria (Zárate, 2002, págs. 131-134). De igual forma, a través de su defensa, también se recalcan los méritos del Estado colombiano para ocupar un espacio regional privilegiado como "portavoz de los pueblos libres de América", ${ }^{34}$ acudiendo adicionalmente a una interpretación textual y autorizada de los tratados que se celebraron en los dos siglos anteriores.

32 Para Jorge Luis Esquirol (2012, págs. 558-559), los tratados más relevantes son cuatro: 1) Convención sobre el Derecho de Asilo (La Habana, 1928). 2) Convenio sobre Asilo Político adoptado en la Séptima Conferencia Internacional de Estados Americanos (Montevideo, 1933). 3) Tratado sobre Asilo y Refugio Político suscrito en el Segundo Congreso de Montevideo (1939). 4) Décima Conferencia Interamericana (Caracas, 1954)

33 "La generosidad, el espíritu humanitario y esencialmente cristiano de esta institución es el alma de la América Latina. Creación espontánea del genio mismo de nuestro pueblo, la institución del asilo ha ido perfeccionándose y estructurándose hasta convertirse hoy en motivo de orgullo legítimo para el Derecho internacional americano" (Yepes, 1958, pág. 16).

"Colombia no ha tratado de defender un interés particular sino principios jurídicos generalmente aceptados en la América Latina. Colombia ha considerado que como miembro de la comunidad americana tiene la obligación de trabajar por la integridad de esos principios, que sumados a otros, se hallan efectivamente en vigor en el continente americano y hacen que la política internacional se desarrolle en esa parte del mundo no sobre la base de razones simplemente utilitaristas o materialistas, sino de doctrinas las más nobles. Colombia ha sido fiel a sus principios, a sus tradiciones y fiel igualmente a las tradiciones jurídicas continentales. Afirmando resueltamente, y sin ningún interés egoísta las tendencias que le son comunes con las demás repúblicas americanas" (Caicedo, 1974, págs. 427-428).
Este estadio superior se puede leer como una edad de oro o un momento estelar, cuyo aporte más relevante es proveer la estructura de su doctrina, a través de una visión litigiosa. Dicha estructura se expresó en debates que traducían y sopesaban las tensiones originadas en las políticas latinoamericanas sobre seguridad y no-intervención, coherentes al inicio de la guerra fría.

Por ende, el eje discursivo giró en torno a las expectativas sobre los pronunciamientos de la Corte Internacional de Justicia, en relación con los siguientes puntos: a) La obligatoriedad jurídica del asilo político, b) Criterios para establecer la titularidad del derecho de un perseguido, c) Reglas para diferenciar entre delincuente político y delincuente común, d) Mecanismos para minimizar los riesgos del abuso del asilo, y e) El reconocimiento de la costumbre como mandato vinculante (Ronning, 1965a, págs. 132-154).

Adicionalmente, la aparición de la lectura secular constituyó una forma complementaria a la visión naturalista. Con ella se perseguía incentivar el diálogo y las alianzas estratégicas incluyentes hacia el auditorio eurocéntrico. El motivo más atractivo para seducir a la familia civilizada apuntaba a la posibilidad de obtener riquezas intelectuales de una comunidad tremendamente creativa e imaginativa, siempre y cuando fuera aceptada como tal. Desde luego que esta estrategia tenía relación con la idea de una comunidad jurídica regional que impulsaba los rasgos cosmopolitas del derecho.

De acuerdo con el relato del asilo político, la prueba de ese ingenio o el mérito de esa creati- 
vidad estaba en la enorme capacidad para elaborar instituciones a partir de principios universales que veían en la tradición y el conocimiento preexistente europeo la mejor de las herencias. Es decir, la expansión del pensamiento jurídico europeo también podía valorarse a partir de los nuevos aportes. De este modo, las contribuciones jurídicas americanas fortalecían el centro desde la especificidad y desde la originalidad de sus prácticas (Becker, 2006, págs. 290-293). Desde luego, el propósito residía en la defensa de la identidad regional para obtener cierto grado de reconocimiento, autonomía e igualdad. ${ }^{35}$

En aras de acreditar la invención, se hizo énfasis en la fertilidad del contexto social americano, como un terreno fácil para las creaciones del derecho internacional. La narrativa del asilo que se ocupa de su devenir hasta el siglo xIx, y aquella que incorpora los nuevos elementos a partir del caso Haya de la Torre, se niegan decididamente a mencionar pensadores de segunda o autores de ideas derivadas. Todo lo contrario,

35 Una historia institucional del asilo político, que puede ser citada como ejemplo de este aspecto, es la obra presentada por Camilo Reyes Rodríguez ante el Ministerio de Relaciones Exteriores de Colombia, para ascender a la categoría de embajador en la carrera diplomática y consular. En ella se evidencia cómo hasta finales del siglo xx la continuidad inalterable de la tradición narrativa del contribucionismo es uno de los rasgos que más han permanecido, incluyendo el uso de un tono patriótico tácito: "El asilo diplomático es desde el siglo pasado un establecimiento que indica la índole humanista y liberal que caracterizó el nacimiento de la vida internacional de las Repúblicas Latinoamericanas. Al adoptarlo, Latinoamérica hizo un reconocimiento de su propia historia, sembrada de caudillos, revoluciones y contrarrevoluciones; y a su idiosincrasia tolerante, pluralista, amante del derecho y la justicia, y al mismo tiempo profundamente respetuosa de la dignidad del ser humano y de su condición jurídica. Se escribió en el convencimiento de que el respeto al Derecho Internacional es el arma principal de que disponen nuestras Repúblicas para enfrentar los desafíos del siglo xxı. Su afianzamiento es probablemente el único medio para aproximarnos a una comunidad internacional más justa en la que las relaciones entre las Naciones constituyan un factor de equidad, progreso y desarrollo" (Reyes, 1996, pág. vi). se muestra dispuesta a asumir la defensa de un derecho global que estuviera confeccionado en función de las necesidades políticas locales.

Aunque se desconoce cuándo se comenzó a hablar en América, y especialmente entre los crioIlos, del derecho de asilo político propiamente dicho, Becker (2006) sostiene que en el periodo comprendido entre 1880 y 1950 , efectivamente se empezó a consolidar un lenguaje jurídico latinoamericano para debatir y disputar un lugar en el mundo en torno al derecho internacional, destacando su identidad y su visión política. ${ }^{36}$

Aunado a ello, el progresivo sentimiento de patriotismo y solidaridad (Álvarez, 1909, pág. 270), acentuado por un férreo discurso republicanista (Martínez, 2001, págs. 246-250) determinó profunda y transversalmente la construcción de la narrativa del asilo político. Sin embargo, para la década de 1950, si bien existía el binomio patriotismo-solidaridad, hubo dos aspectos que evidentemente dejaron de tener sentido en la narrativa jurídica, quedando relegados definitivamente en el siglo xIx. Primero, el latente temor de sufrir una retaliación europea en los territorios que habían estado bajo el dominio español. ${ }^{37}$ Segundo, el fuerte orgullo que se derivó

36 Esta afirmación se desprende del análisis que Becker hizo de algunos manuales o libros de referencia de derecho internacional, consultados usualmente en universidades y oficinas de abogados. Entre estos autores se destacan, para el caso colombiano: Enrique Gaviria Liévano, Marco Gerardo Monroy Cabra, César Sepúlveda y Modesto Seara Vásquez. Para este autor, el mérito de los tratadistas radica en su capacidad de agrupar en buena medida tres aspectos: a) el pensamiento jurídico latinoamericano, b) el sentido común profesional, y c) la comprensión popular sobre el derecho internacional en la región, lo cual alimenta conocimientos tradicionales nacionales (Becker, 2006, págs. 286-287).

37 "Two basic ideas inspired the development of international law in Latin American during the decolonization period: (1) creation of a confed- 
de la respuesta decepcionante por no haber podido mantener un diálogo respetuoso y recíproco con Europa (Martínez, 2001, pág. 245), pese al auge económico suramericano. ${ }^{38}$

A mediados de siglo xx, el asilo político como discurso había ganado un terreno importante. En el caso colombiano comenzó a promover la imagen de los líderes regionales que gozaban de un gran prestigio internacional. Esto automáticamente impactó en la idea de amor a la patria. En ese sentido, la participación de aquellos líderes en el Consejo de Seguridad de la onu los hacía ver como actores de primer orden en la arena internacional. De igual forma, la creación de la OEA fue determinante para que en el continente se empezara a reforzar la idea de una conciencia jurídica propiamente americana. ${ }^{39}$

eration of nation of the Americas for consolidation and protection of newly won freedom and independence; and (2) adoption of a set of legal principles which would be in force between the emerging states. It was only to be expected that the newly independent Latin American countries would reaffirm their freedom, equality and independence and at first would be confronting the European establishment" (Caminos, 1986, págs. 157-158).

38 Esta situación ahondó el deseo de romper resueltamente con el pasado colonial. Este propósito es perceptible en la preocupación de Carlos Calvo al combatir la prevención de los lectores europeos frente al progreso material y comercial de América del Sur. Su argumento en este sentido consistía en demostrar que el aumento del intercambio comercial había impulsado el grado de riqueza, prosperidad, bienestar y civilización, al punto que era superior a algunos pueblos de Europa (ver el acápite América Latina, en Calvo, 1862, pág. II).

39 "Particular textbooks outline in an extremely formal way each of the American Conference, adding a paragraph about the decisions adopted and describing the achievements that led to the creation of the Organization of American States (OAS) and the inter-American system. Then they also devote a considerable number of pages to illustrate the formal structure of the OAS. In this regard, these textbooks highlight the Latin American contribution to international law, as the founders of the regional organization, as well as the League of Nations and the United Nations, had the Latin American experience in mind" (Becker, 2006a, pág. 292).
Con todo, el caso Víctor Raúl Haya de la Torre heredó de la narrativa del asilo político del siglo XIx una lógica de pensamiento que involucró los intereses de una conciencia colectiva regional. Esta lógica superaba la idea de la protección y la salvaguarda de las élites, simplemente. ${ }^{40} \mathrm{Se}$ trataba de un concepto amplio que respondía a una "conciencia jurídica criolla" ${ }^{41}$ que veía en el lenguaje del derecho, una vía estratégica para alcanzar el anhelo de la autonomía y la igualdad.

Las similitudes con los problemas jurídicos del siglo anterior apuntaban a la lucha por la identidad y el reconocimiento. Los abogados "criollos" (Obregón, 2010, págs. 5-6) y "republicanos" (Obregón, 2006b, pág. 989), tenían como objeto común el énfasis multicultural de los diálogos sobre opiniones, doctrinas y principios del derecho latino americano, en los cuales se subraya-

40 Figuras como Andrés Bello (Obregón, 2005, págs. 151-152; 2010, pág. 17), Carlos Calvo (Obregón, 2006a, pág. 257), Manuel Anastasio Fuentes (Obregón, 2006a, pág. 257), José María Samper (Obregón, 2006a, págs. 259-262) y Alejandro Álvarez (Obregón, 2006b, págs. 993-994), evidenciaron una preocupación permanente por estructurar un proyecto regional, cuyo impacto influenciara decisivamente una selecta audiencia extranjera. Este aspecto es relevante para el estudio de la narrativa del asilo político, puesto que justificaría lo siguiente: a los abogados latinoamericanos desde el siglo xIX les ha resultado natural escribir en más de una dirección política, no limitada al ámbito interno.

41 Este concepto fue acuñado por Liliana Obregón y resulta útil para el análisis de la narrativa sobre el asilo político, en la medida en que identifica corrientes intelectuales y aparatos críticos que explican claramente la recepción de ideas extranjeras, desde comienzos del siglo XIX en el pensamiento jurídico latinoamericano, a saber: "By a Creole legal consciousness I mean a broad set of problems, strategies, uses, and ideas about law that were shared among a group of Latin American lawyers in the post-independence era. I do not include specific legal rules or theories about the law as part of its consciousness but rather a wide acceptance of a regional identity of the law, both in its American particularism and its European roots, an adjudication practice that allows for the reception and appropriation of foreign ideas and theories about the law as part of a new application to local needs or interest, and a continuous "will to civilization" in which the purpose is to improve the status of local civilization but with Europe as a reference" (Obregón, 2006b, pág. 985). 
ba la especificidad y la originalidad de lo local. Se trató por ende del empleo de un discurso que propendía por la validación y la legitimación de los intereses criollos/americanos, frente a un auditorio que reposaba en los centros académicos europeos.

La estrategia responde, a su vez, a una de las tendencias más usuales de la literatura del siglo XIX: continuar participando en los debates internacionales en una lógica que legitimaba la condición de incluido/excluido respecto del derecho internacional americano, conforme a los siguientes binomios: a) el universalismo versus el particularismo, y b) la barbarie versus la civilización (Obregón, 2006a, pág. 250).

Adicionalmente, el orgullo también fue insumo trascendental en la defensa del caso Haya de la Torre, en la medida en que el asilo político era presentado como la institución jurídica americana. Por un lado, se quería ver como la expresión de una tradición inmemorial civilizada que era practicada tanto en la antigua Grecia pagana como en la Europa cristiana monárquica. De otro, aparecía como el fruto del ingenio jurídico americano, frente a aquellas agresiones que pudiera sufrir cualquier caudillo en desgracia.

En este punto es preciso aclarar, que cuando los abogados internacionalistas criollos y colombianos abordaron el asilo político como la garantía humanitaria y cristiana de los líderes probos con ideales altruistas, evitaron hablar en primera persona, soslayando que sus intereses estuvieran representados en la formación de este nuevo lenguaje. Sin embargo, estos delicados giros les permitieron traducir sus intereses en el terreno del eurocentrismo, en forma natural y mayoritariamente aceptada.

\section{La lectura sobre la memoria amenazada: poder e identidad}

Finalmente, más allá de promover la lectura secular, el caso Víctor Raúl Haya de la Torre impulsó en la narrativa una nueva corriente de escritura que se caracteriza por expulsar parte del descontento gremial en contra de la Corte Internacional de Justicia, recurriendo a la idea de la ignorancia y la incapacidad para entender la psicología o la idiosincrasia de un pueblo, que por naturaleza es inventivo.

Esta corriente marca la literatura de la segunda mitad del siglo xx con el interés de provocar el descrédito de los magistrados de la Corte, como un acto revanchista y de interés nacional y continental. En aras de este propósito, todo el metarrelato adopta la postura radical de rectificar cada uno de los acontecimientos que integran la historia verdadera del asilo. La exaltación no se expresa como en la literatura anterior a 1949, sino que se enfatiza la imagen de un ataque desmedido a Colombia, una victimización inmerecida que solo puede detenerse en virtud del legítimo derecho de defensa.

Por tanto, se observa un ensayo por inculcar una retórica que exhibe el análisis en detalle sobre cómo la memoria y el pasado de las masas pueden servir como un instrumento de lucha en contra de los intentos por desaparecer de un plumazo, a través de una pieza jurídica execra- 
ble, aquellos bienes y patrimonios inmateriales de una nación y de un continente.

La voluntad de rectificar el acontecimiento que contradice y confronta el enemigo político, agravado por el aval que recibe el pensamiento excluyente del eurocentrismo, parece haber traspasado los mínimos de lo moralmente aceptable. Se trata, entonces, de un grito de guerra que va a toda costa en busca de su identidad amenazada por la historia tergiversada.

\section{CONCLUSIONES}

\section{A. La insatisfacción por la historia tradicional}

En este acápite deseo plantear una reflexión: hacer una lectura del asilo político en su acepción diplomática/latinoamericana, a partir de algunos elementos de la historia del derecho, podría resultar importante para una comunidad jurídica, en aras de hacer más coherente la función reguladora del derecho, atando los efectos normativos que se pueden producir en la esfera social.

La dogmática del asilo podría perseguir una aspiración legítima de armonizar debates que integren problemas del tiempo presente relativos a la soberanía, la extraterritorialidad y los límites del ejercicio de la jurisdicción penal, más orientados a dar luces sobre situaciones actuales y globales, cada vez más relevantes en las agendas internacionales de los Estados. ¿Qué puede decir la literatura jurídica sobre esta institución estando anestesiada e imbuida en la historiografía hispanoamericana del siglo xIx sobre este asunto?

La producción bibliográfica sobre historias patrias y héroes bolivarianos se muestra cada vez más incapaz para decir algo sobre la realidad internacional vigente. La indiferencia que hay sobre este asunto promueve repeticiones mecánicas-automáticas de un discurso cuyos efectos de verdad cesaron hace más de cincuenta años, cuando el auditorio que tenía interés en el asilo político no tuvo más remedio que ver a Víctor Raúl Haya de la Torre partir hacia la capital mexicana, en abril de 1954.

El legado que quedó, es lo que traté de mencionar arriba. Un conjunto de imágenes que sobreviven en el presente a pesar de su anacronismo. Es la vigencia de la prisión historiográfica cuya unidad de sentido original ancló la dogmática y la narrativa en función de unos ejes. Cuestionar entonces el exhorto por conseguir la aprobación del lector, y la voluntad de rectificar el orden de los acontecimientos, podría ser el inicio por formular una narrativa diferente de la que dominó las aspiraciones hasta mediados del siglo xx.

\section{Referencias}

Álvarez, A. (1909). Latin America and International Law. Obtenido de American Society of International Law: http://www.jstor.org/stable/2186127.

Becker Lorca, A. (2006). International Law in Latin America or Latin American International 
Law? Rise, Fall and Retrieval or a Tradition of Legal Thinking and Political Imagination. Harvard International Law Journal, 47(1), 283305.

Bollini Shaw, C. y Moreno Quintana, L. (1950). Derecho Internacional Público. Sistema nacional de derecho y política internacional. Metodología, estructura internacional, organización de las relaciones internacionales. Buenos Aires: Ediciones Librería del Colegio.

Caicedo Castilla, J. (1961). El panamericanismo. Buenos Aires: Roque Depalma Editor.

Caicedo Castilla, J. (1974). Historia Diplomática, Historia Extensa de Colombia (t. I, Vol. XVII). Bogotá: Academia Colombiana de Historia/ Ediciones Lerner.

Calvo, C. (1862). Colección completa de los tratados, convenciones, capitulaciones, armisticios y otros actos diplomáticos de todos los Estados de la América Latina comprendidos entre el Golfo de Méjico y el Cabo de Hornos, desde el año de 1493 hasta nuestros días, precedidos de una memoria sobre el estado actual de la América, de cuadros estadísticos, de un diccionario diplomático, y de una noticia histórica sobre cada uno de los tratados más importantes (t. I). París: Librería de A. Durand.

Camacho Arango, C. H. (2013). Le Conflit de Leticia (1932-1933) et les armées du Pérou et de la Colombie: histoire-récit, histoire comparée, histoire croisée (tesis inédita de doctorado). Université Panthéon-Sorbone, París, France.

Caminos, H. (1986). The Latin American Contribution to International Law. Obtenido de American Society of International Law: http:// www.jstor.org/stable/25658305.

Cavelier Gaviria, G. (1960). La política internacional de Colombia. El asilo diplomático (Tercera ed., t. IV). Bogotá: Editorial Iqueima.

Cavelier Gaviria, G. (1997). La política internacional de Colombia. Bogotá: Universidad Externado de Colombia, Facultad de Finanzas, Gobierno y Relaciones Internacionales.

Colmenares, G. (1986). La historia de la revolución de José Manuel Restrepo: una prisión historiográfica. En G. Colmenares, Z. Díaz, J. Escorcia y F. Zuluaga (Edits.), La Independencia: ensayos de historia social (págs. 7-23). Bogotá: Instituto Colombiano de Cultura.

Colmenares, G. (1987). Las convenciones contra la cultura. Bogotá: Tercer Mundo Editores.

Colombian-Peruvian asylum case, Judgement of November $20^{\text {th }}, 1950$. Reports 1950,266 389.

Deas, M. (2006). Del poder y la gramática: y otros ensayos sobre historia, política y literatura colombianas. Bogotá: Taurus.

Díaz Ángel, S., Muñoz Arbeláez, S. y Nieto Olarte, M. (2010). Ensamblando la nación: cartogra- 
fía y política en la historia de Colombia. Bogotá: Universidad de los Andes.

Diggelmann, O. (2012). The Periodization of the History of International Law. En B. Fassbender y A. Peters (Edits.), The Oxford Handbook of the History of International Law (págs. 9971011). Oxford: Oxford University Press.

Esquirol, J. (2012). Latin America. En B. Fassbender y A. Peters (Edits.), The Oxford Handbook of the History of International Law (págs. 553-577). Oxford: Oxford University Press.

Evans, A. (1952). The Colombian-Peruvian Asylum Case: The Practice of Diplomatic Asylum. Obtenido de ssTOR: http://www.jstor.org/ stable/1950767.

Fazio Vengoa, H. (1991). La “nueva historia” francesa: radiografía de una historia. Historia Crítica, (5), 35-51.

Febvre, L. (1974). Combates por la historia. Barcelona: Editorial Ariel.

Garzón Cortés, J. (1982). El asilo americano: sus orígenes, su naturaleza jurídica, su evolución. Tunja, Boyacá, Colombia: Talleres Gráficos de la Caja Popular Cooperativa.

Gaviria Liévano, E. (1988). Derecho Internacional Público. Bogotá: Temis.

González, I. (2012). La revista Bolívar y el discurso conservador sobre hispanidad y nación. En R. Sierra (Edit.), La restauración conservadora, 1946-1957 (págs. 371-408). Bogotá: Uni- versidad Nacional de Colombia, Facultad de Ciencias Humanas.

Harley, J. B. (2005). La nueva naturaleza de los mapas: ensayos sobre historia de la cartografía. México: Fondo de Cultura Económica.

Jaramillo Sierra, I. (2013). Introducción. En I. Jaramillo Sierra, Derecho y familia en Colombia. Historias de raza, género y propiedad (15401980) (págs. 3-39). Bogotá: Universidad de los Andes, Facultad de Derecho, Ediciones Uniandes.

Legación de Colombia en España. (1933). El gran triunfo de Colombia. Los derechos de Colombia y la actitud del gobierno del Perú, juzgados por la Sociedad de las Naciones y los Estados Unidos de América. Madrid: Imprenta de Juan Pueyo.

Luque Ángel, E. (1959). El derecho de asilo (tesis doctoral). Facultad de Ciencias Económicas y Jurídicas. Pontificia Universidad Católica Javeriana. Bogotá.

Martínez, F. (2001). El nacionalismo cosmopolita. La referencia europea en la construcción nacional en Colombia, 1845-1900. Bogotá: Banco de la República, Instituto Francés de Estudios Andinos.

Ministerio de Relaciones Exteriores de Colombia. (1951). La opinión americana y el derecho de asilo. Plebiscito internacional en favor de las tesis colombianas. Bogotá: Departamento de Información y Publicaciones y Organismos Internacionales, Imprenta Nacional. 
Monateri, P., Samuel, G. (2006). La invención del derecho privado. Bogotá: Siglo del Hombre Editores/Universidad de los Andes/Facultad de Derecho, Pontificia Universidad Javeriana/Instituto Pensar.

Monroy Cabra, M. (2002). Derecho International Público. Bogotá: Temis.

Niño Delgado, A. Y. (s.f.). Narraciones del conflicto colombo peruano: unidad nacional $y$ construcción del enemigo (tesis inédita de maestría). Universidad de los Andes, Bogotá, Colombia.

Obregón Tarazona, L. (2005). The Colluding Worlds of the Lawyer, the Scholar and the Policymaker: A View of International Law from Latin America. Wisconsin International Law Journal, 23(1), 145-172.

Obregón Tarazona, L. (2006a). Completing Civilization: Creole Consciousness and International Law in Nineteenth Century Latin America. En A. Orford (Edit.), International Law and its Others (págs. 247-264). Cambridge: Cambridge University Press.

Obregón Tarazona, L. (2006b). Noted for Dissent: The International Life of Alejandro Álvarez, Leiden Journal of International Law, 19(4), 9831016.

Obregón Tarazona, L. (2010). Construyendo la región americana: Andrés Bello y el derecho internacional. Revista de Derecho Público, (24), 3-22.
Obregón Tarazona, L. (2012). The Civilized and the Uncivilized. En B. Fassbender y A. Peters (Edits.), The Oxford Handbook of the History of International Law (págs. 997-1011). Oxford: Oxford University Press.

Oppenheim, L. (1961). Tratado de derecho internacional público. Barcelona: Bosch.

Planas-Suárez, S. (1953). El asilo diplomático. Estudio jurídico y político sobre este execrable uso latinoamericano destructor de la soberanía nacional y de la cordialidad internacional. Buenos Aires: Imprenta López.

Reyes Rodríguez, C. (1996). La institución del asilo diplomático: origen, evolución y perspectivas. (Trabajo presentado como requisito para el ascenso de la categoría de Embajador en la carrera diplomática y consular). Santafé de Bogotá, D. C.: Academia Diplomática de San Carlos, Ministerio de Relaciones Exteriores.

Ronning, C. (1961). Intervention, International Law, and the Inter-American System. Obtenido de JSTOR: http://www.jstor.org/stable/164974.

Ronning, C. (1965a). Derecho y política en la diplomacia interamericana. México: Unión Tipográfica Editorial Hispano Americana, Editorial Rebasa.

Ronning, C. (1965b). Diplomatic Asylum. Legal Norms and Political Reality in Latin American Relations. The Hague, Netherlands: Martinus Nijhoff. 
San Juan, C. (2003). Informe general de la investigación. En L. Franco. (Coord.), El asilo y la protección internacional de los refugiados en América Latina. Análisis crítico del dualismo "asilo-refugio" a la luz del derecho internacional de los derechos humanos (págs. 1971). Buenos Aires: Universidad Nacional de Lanús/ACNUR/Siglo XXI Editores.

Sanz de Santamaría, C. (1978). Fin del asilo del doctor Víctor Raúl Haya de la Torre en la Embajada de Colombia en Lima 1954. (Negociaciones entre los representantes del Perú y los de Colombia). Bogotá: Fundación Centenario del Banco de Colombia.

Seara Vásquez, M. (1982). Derecho internacional público. México: Editorial Porrúa.

Serje de la Ossa, M. R. (2011). El revés de la nación: territorios salvajes, fronteras y tierras de nadie. Bogotá: Universidad de los Andes.

Ursúa, F. (1952). El asilo diplomático. Comentarios sobre la sentencia de la Corte Internacional de Justicia en el asunto concedido en la Embajada de Colombia en Lima al Dr. Víctor Raúl Haya de la Torre. México D. F.: Editorial Cultura T. G., S. A.

Villa Alzate, G. (1992). El derecho de asilo en el derecho internacional general y en el derecho internacional público. Revista de Derecho Público, (2), 103-116.
Villegas del Castillo, C. (2009). Historia y derecho: la interdisciplinariedad del derecho y los retos de la historia del derecho. Revista de Derecho Público, (22), 3-22.

Yepes, J. M. (1933). Le conflit entre la Colombie et le Pérou (affaire de Leticia) devant le Droit International. París: Jouve \& C. Editeurs.

Yepes, J. M. (1956). Una política internacional para Colombia. "Colombia, sin grandeza, no es Colombia". Discurso de posesión del Profesor doctor J. M. Yepes como miembro de número de la Academia Colombiana de Jurisprudencia en el sillón ocupado antes por el doctor Eduardo Restrepo Sáenz, ex-Ministro de Relaciones Exteriores, y contestación del Académico Mgr. Rudesindo López Lleras. Separata de la Revista de la Academia Colombiana de Jurisprudencia, XXV(173).

Yepes, J. M. (1958). El derecho de asilo: síntesis histórica, jurídica, política y filosófica. El asilo en Colombia; una página de historia diplomática en Colombia y América. Universitas (15). Bogotá: Pontificia Universidad Javeriana.

Zárate, L. (2002). El asilo en el derecho internacional americano. Con un apéndice de la Corte Internacional de Justicia y de anexos de la Cancillería de Colombia. Bogotá: Editorial Leyer. 